
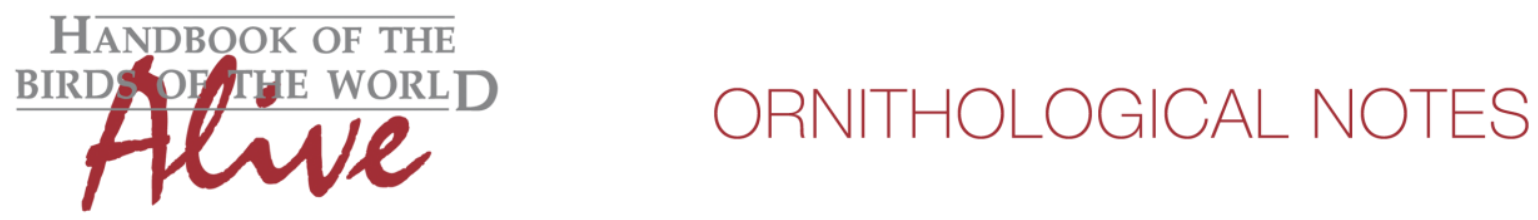

\title{
Notes on the vocalizations of Yellow-margined Flycatcher (Tolmomyias assimilis)
}

\author{
Peter Boesman
}

In the following we briefly analyze and compare voice of the different races of Yellowmargined Flycatcher (Tolmomyias assimilis). We also try to quantify the extent of any vocal differences using the criteria proposed by Tobias et al. (2010), as a support for taxonomic review. We have made use of sound recordings available on-line from Xeno Canto (XC) and Macaulay Library (ML).

There are clearly 3 vocal groups (Fig. 1):

\section{Central America and Choco region T. a. flavotectus $(n=8)$}

Song is very constant: a series of 4-5 high-pitched notes, with a longer pause after first note and subsequent 3-4 notes slightly higher-pitched, equally paced and nearly identical. On a sonogram notes are clear-cut nicely rounded and overslurred.

$\begin{array}{ll}\text { max. freq. } & 7350-8500 \mathrm{~Hz} \\ \text { max. note length } & 0.11-0.16 \mathrm{~s} \\ \text { min. freq. } & 6100-7100 \mathrm{~Hz} \\ \text { min. pause } & 0.30-0.39 \mathrm{~s} \\ \text { total freq. range } & 4900-6000 \mathrm{~Hz} \\ \text { min note length } & 0.067-0.15 \mathrm{~s} \\ \text { freq. bands } & 1\end{array}$

\section{N of Amazon T. a. neglectus T. a. examinatus ( $n=6)$}

Song is a variable series of a few drawn-out extremely nasal, almost screaming notes, on a sonogram apparent by a large number of equidistant frequency bands. All notes at about the same pitch, and are symmetrical and overslurred.

$\begin{array}{ll}\text { max. freq. } & 3450-5000 \mathrm{~Hz} \\ \text { max. note length } & 0.36-0.50 \mathrm{~s} \\ \text { min. freq. } & 3200-5000 \mathrm{~Hz} \\ \text { min. pause } & 0.32-1.15 \mathrm{~s} \\ \text { total freq. range } & 1800-3500 \mathrm{~Hz} \\ \text { min note length } & 0.34-0.46 \mathrm{~s} \\ \text { freq. bands } & 7-11 \text { (at about } 300 \mathrm{~Hz} \text { distance) }\end{array}$

S of Amazon T. a. obscuriceps T. a. clarus T. a. assimilis T. a. paraensis T. a. calamae $(n=10)$ Song is a variable series of a few slightly buzzy notes. Notes typically rise in pitch, and are asymmetrical on a sonogram. Note shapes vary considerably among races.

$\begin{array}{ll}\text { max. freq. } & 3100-4140 \mathrm{~Hz} \\ \text { max. note length } & 0.22-0.48 \mathrm{~s} \\ \text { min. freq. } & 2500-3100 \mathrm{~Hz} \\ \text { min. pause } & 0.20-0.9 \mathrm{~s} \\ \text { total freq. range } & 1100-2500 \mathrm{~Hz} \\ \text { min note length } & 0.20-0.44 \mathrm{~s} \\ \text { freq. bands } & 1 \text { (with slightly burry appearance) }\end{array}$




\section{HANDBOOK OF THE \\ BIRDS PF/THE WORLD}

\section{ORNITHOLOGICAL NOTES}
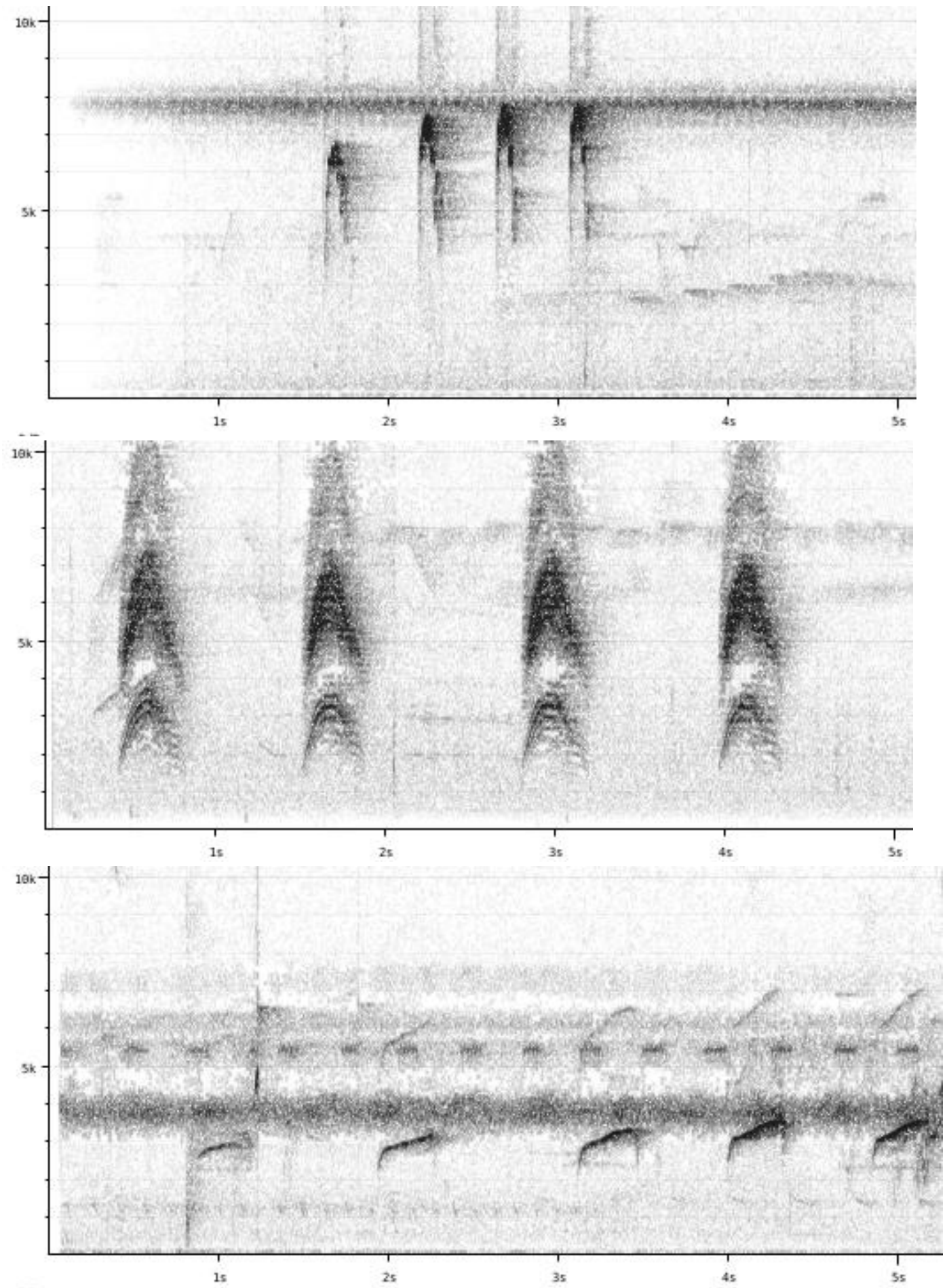

Figure 1: from top to bottom: Typical song of flavotectus, $\mathrm{N}$ of Amazon group and $\mathrm{S}$ of Amazon group 

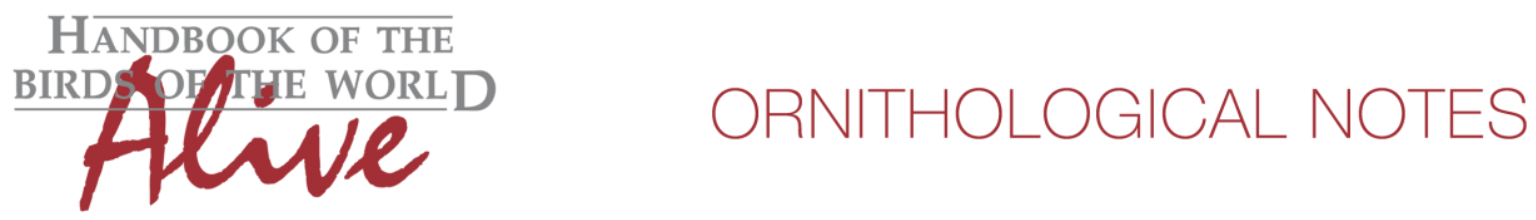

flavotectus is clearly different from all remaining races, reaching much higher frequencies (score 3-4) and having a very large frequency range (score 3), having much shorter notes (score 3-4). The constant rhythmic pattern is also diagnostic (other vocal groups only occasionally having this rhythm). When applying Tobias criteria, this would lead to a total vocal score of about 7.

$\mathrm{N}$ of Amazon T. a. neglectus T. a. examinatus is readily identified by its extremely harsh notes. It differs from birds $S$ of the Amazon by reaching slightly higher frequencies (score 1 ) with all notes at about the same pitch (score 2-3) and the screechy notes reflected on a sonogram by many equidistant frequency bands (score 2-3). Total vocal score about 5.

There are still differences among races south of the Amazon, principally in note shape, which would require further work to unravel.

In this context, there is also the newly described sucunduri $(n=2)$

max. freq.

$3750-4400 \mathrm{~Hz}$

max. note length $\quad 0.36-0.40 \mathrm{~s}$

min. freq. $\quad 3000-3500 \mathrm{~Hz}$

min. pause $\quad 0.3-0.6 \mathrm{~s}$

total freq. range $\quad 1600-2800 \mathrm{~Hz}$

min note length $\quad 0.24-0.30 \mathrm{~s}$

freq. bands $\quad 1$ (with distinct modulated appearance)

Based on these 2 recordings (available from the IBC website) and above measurements, overall song structure is similar to birds $S$ of the Amazon, with none of the basic sound parameters highly distinct (a score of 1 for a higher max. freq. for any note in the song). What is most distinct is the 'modulated' note shape, which in fact is a composite of a fast series of pulses (there are a few examples of other races $\mathrm{S}$ of the Amazon showing some modulation, but never so outspoken as the sucunduri examples) (score 1-2). This would lead to a vocal score of 2-3 vs. birds S of the Amazon (and about 4 vs. birds $\mathrm{N}$ of the Amazon).

This note was finalized on 3rd September 2015, using sound recordings available on-line at that moment. We would like to thank in particular the many sound recordists who placed their recordings for this species on XC.

\section{References}

Tobias, J.A., Seddon, N., Spottiswoode, C.N., Pilgrim, J.D., Fishpool, L.D.C. \& Collar, N.J. (2010). Quantitative criteria for species delimitation. Ibis 152(4): 724-746.

\section{Recommended citation}

Boesman, P. (2016). Notes on the vocalizations of Yellow-margined Flycatcher (Tolmomyias assimilis). HBW Alive Ornithological Note 121. In: Handbook of the Birds of the World Alive. Lynx Edicions, Barcelona. (retrieved from http://www.hbw.com/node/932028 on 4 August 2016). 